\title{
Microbial respiration and ecoenzyme activity in sediments from the Gulf of Mexico hypoxic zone
}

\author{
Brian H. Hill ${ }^{1, *}$, Colleen M. Elonen ${ }^{1}$, Leroy E. Anderson ${ }^{1}$, John C. Lehrter ${ }^{2}$ \\ ${ }^{1}$ US Environmental Protection Agency, Office of Research and Development, \\ National Health and Environmental Effects Research Laboratory, Mid-Continent Ecology Division, 6201 Congdon Blvd., \\ Duluth, MN 55804, USA \\ ${ }^{2}$ US Environmental Protection Agency, Office of Research and Development, \\ National Health and Environmental Effects Research Laboratory, Gulf Ecology Division, 1 Sabine Island Drive, Gulf Breeze, \\ FL 32561, USA
}

\begin{abstract}
Sediment chemistry (total carbon [TC], total nitrogen [TN], total phosphorus [TP]), microbial respiration (dehydrogenase activity, DHA), and ecoenzyme activity (EEA) were measured in 4 zones of similarity in the northern Gulf of Mexico (GOM). DHA and EEA reflected the differences in $\mathrm{C}$ and $\mathrm{N}$ availability associated with proximity to the discharges of the Mississippi and Atchafalaya Rivers, and EEA represented the interface between microbial demands for, and environmental supplies of, nutrients. DHA was positively correlated with $\beta$-glucosidase $(B G, r=$ $0.30)$, [ $\beta$-N-acetyl glucosaminidase + L-leucine amino peptidase] ([NAG + LAP], 0.65), acid phosphatase (AP, 0.17), and aryl sulfatase (SULF, 0.42). EEAs were positively correlated with each other (0.34-0.76). DHA (0.22-0.33), [NAG + LAP] $(0.46-0.64)$, and SULF $(0.17-0.56)$ were positively correlated with TC, TN, and TP, while BG (0.58-0.60) and AP (0.50-0.58) were correlated only with TC and TN. Carbon use efficiency (CUE) and organic C decomposition rate $(M)$, both based on ecoenzyme models, were positively correlated with TN and TC $(0.43-0.46)$ and TC, TN, and TP $(0.24-0.60)$, respectively. Modeled respiration $\left(R_{\mathrm{m}}\right)$, based on $M, \mathrm{TC}$, and sediment bulk density, was correlated with sediment chemistry (0.17-0.90), and with DHA (0.50). All measured chemistry, DHA, EEA, and modeled decomposition parameters exhibited significant cruise, zone, and sediment depth effects, but few significant interaction effects. Structural equation modeling (SEM) revealed a causal relationship between sediment chemistry, EEA, and DHA, explaining $46 \%$ of the variance in DHA. As such, the relative activities of the functional classes of ecoenzymes are both a measure of nutrient availability and ecosystem metabolism that may be used to assess large-scale phenomena, such as regional impacts of anthropogenic disturbances.
\end{abstract}

KEY WORDS: Ecoenzymes - Gulf of Mexico - Hypoxia $\cdot$ Respiration $\cdot$ Sediments $\cdot$ Structural equation modeling

Resale or republication not permitted without written consent of the publisher

\section{INTRODUCTION}

There are more than 400 scientifically documented cases of eutrophication-induced coastal zone hypoxia (Diaz \& Rosenberg 2008). The earliest reports were from the Adriatic and Black Seas, but coastal hypoxic zones are now associated with most major population centers and with drainage basins domi- nated by agricultural land uses that export large quantities of nutrients (Rabalais et al. 1996, Diaz \& Rosenberg 2008, Conley et al. 2009, Bianchi et al. 2010). Coastal zone hypoxia ranges from periodic to persistent with the majority being seasonal, summer occurrences (Diaz \& Rosenberg 2008). Such is the case with the northern Gulf of Mexico (GOM), where the vertical salinity gradients, driven by freshwater 
inputs from the Mississippi River, causes stratification of coastal waters and limits mixing of the more aerated surface layer with the less aerated (hypoxic) lower layers. Organic matter derived from terrestrial sources and produced by phytoplankton in response to Mississippi River nutrient influx, fuels respiration beneath the pycnocline leading to hypoxic or anoxic waters and sediments (Rabalais et al. 1996, Arnosti \& Holmer 2003, Emerson \& Hedges 2006, Bianchi et al. 2010).

Organic C processing in GOM sediments involves both aerobic and anaerobic pathways, following a thermodynamic cascade of electron acceptors: $\mathrm{O}_{2}$, followed by $\mathrm{NO}_{3}{ }^{-}, \mathrm{MnO}_{2}, \mathrm{Fe}_{2} \mathrm{O}_{3}$, and $\mathrm{SO}_{4}{ }^{2-}$ reduction, and finally methanogenesis (Emerson \& Hedges 2006). The presence of $\mathrm{O}_{2}$ also facilitates the oxidation of reduced species $\left(\mathrm{NH}_{4}{ }^{+}, \mathrm{Mn}^{2+}, \mathrm{Fe}^{2+}\right.$, and $\left.\mathrm{HS}^{-}\right)$ providing recycled electron acceptors for further anaerobic respiratory reduction. In the absence of $\mathrm{O}_{2}, \mathrm{NO}_{3}{ }^{-}$and $\mathrm{MnO}_{2}$ are quickly exhausted and $\mathrm{Fe}^{3+}$ and $\mathrm{SO}_{4}{ }^{2-}$ reduction become the dominant respiratory pathways (Emerson \& Hedges 2006, Morse \& Eldridge 2007). Regardless of the respiratory pathway, the oxidation of reduced carbon compounds, such as glucose, results in the release of 4 electrons which are transported via dehydrogenase enzymes (DHA) into the respiratory electron transport system of microbial cells (Emerson \& Hedges 2006).

Organic matter diagenesis in the open ocean is dominated by water-column processes such that approximately $90 \%$ of the organic matter in suspension is aerobically decomposed before reaching the sea bed (Emerson \& Hedges 2006). In shallow, continental shelf regions of the ocean, such as the northern GOM, 80 to $90 \%$ of the water-column particulate organic matter sinks to the sea bed before being decomposed (Morse \& Eldridge 2007, Bianchi et al. 2010). Once deposited on the sea bed, organic matter is processed by both aerobic and anaerobic processes, with the relative balance between oxic and anoxic respiration depending on the amount of organic matter loading and the influx of oxygenated waters. In oligotrophic systems, where organic matter loading is low, benthic respiration may be predominantly aerobic, but under large organic matter loading related to eutrophic conditions, benthic respiration is mainly anaerobic and dominated by sulfate reduction (Jorgensen 1982, Sampou \& Oviatt 1991).

Cellular respiration is the primary pathway for organic $\mathrm{C}$ mineralization. Whether the respiration occurs in the presence of $\mathrm{O}_{2}$ or not, the same electron transport system (ETS) supports the generation and transfer of electrons $\left(\mathrm{e}^{-}\right)$as the C-containing compound is degraded and energy released (Broberg 1985). Respiration associated with GOM sediments has been measured as $\mathrm{O}_{2}$ consumption or production of dissolved inorganic carbon (e.g. Rowe et al. 2002, Murrell \& Lehrter 2011, Lehrter et al. 2012), but may also be measured as ETS activity using DHA (Trevors et al. 1982, Broberg 1985, Hill et al. 2002, 2010). DHA, which can be used in both aerobic and anaerobic environments, provides a measure of the activity of oxidation-reduction enzymes responsible for dissociating $\mathrm{H}^{+}$from $\mathrm{H}_{2} \mathrm{O}$, generating $2 \mathrm{e}^{-}$for the ETS process. Measurement of DHA is based on intercepting $\mathrm{e}^{-}$flow through mitochondrial and microsomal ETS using a surrogate electron acceptor, 2-( $p$-iodophenyl)-3-( $p$-nitrophenyl)-5-phenyl tetrazolium chloride (INT), which has a redox potential slightly higher than that of the coenzyme UQcytochrome b complex and similar cytochrome electron acceptors used by prokaryotic organisms (Packard 1971, Broberg 1985). While anaerobic organisms use different $\mathrm{e}^{-}$acceptors than $\mathrm{O}_{2}$ (e.g. $\mathrm{NO}_{3}{ }^{-}, \mathrm{SO}_{4}{ }^{2-}$ ) and have different respiratory enzymes, DHA measurement is nonetheless applicable to anaerobic ETS activity (Packard 1971). On a molar basis, 2 moles of DHA are equivalent to 1 mole of $\mathrm{CO}_{2}$ respired (Broberg 1985).

Nutrient cycling in aquatic ecosystems is mediated by microbial assemblages and their metabolic activities. In addition to cellular respiration, microbial assemblages produce ecoenzymes to catalyze the degradation of organic matter in order to acquire organically-bound carbon and nutrients (Sinsabaugh \& Foreman 2001, Arnosti et al. 2009, Sinsabaugh et al. 2009). Several terms have been used to describe the distribution or origin of enzymes found outside of microbial cells, including extracellular enzymes, ectoenzymes, and exoenzymes, with varying definitions. In recent papers, we use the term ecoenzyme to broadly encompass all enzymes located outside the confines of intact cell membranes regardless of whether such enzymes enter the environment by secretion or lysis (Sinsabaugh et al. 2009). This definition provides the closest correspondence between environmental enzyme activity and organic matter decomposition. Of particular interest are glycosidases (linked to labile organic carbon processing), glucosaminidases and peptidases (chitin and protein degradation resulting in nitrogen acquisition), and phosphatases related to phosphorus acquisition. Microbial ecoenzyme activity (EEA) is positively related to sediment nutrient concentrations (Sinsabaugh et al. 2009), organic carbon lability (Arnosti 
et al. 2009, Sinsabaugh \& Follstad Shah 2011), and microbial metabolism (Hill et al. 2010, 2012, Sinsabaugh et al. 2012).

Microbial carbon use efficiency (CUE) is a measure of the relative apportionment of $\mathrm{C}$ utilization for microbial growth versus the energetic requirements (as respiration) to support existing microbial biomass (Keiblinger et al. 2010, Manzoni et al. 2012, Sinsabaugh et al. 2013). Values for CUE range from near zero to a thermodynamic maximum of 0.60 , though empirical estimates from a wide range of conditions converge on a CUE value of 0.30 (Sinsabaugh et al. 2013). Higher CUE suggests more efficient growth and lower $\mathrm{C}$ losses (respiration, excretion) to the environment (Manzoni et al. 2012). CUE decreases with increasing temperature, though the response is weak within the temperature range of most studies (Manzoni et al. 2012). Resource C:N:P stoichiometry has proven to be a more important regulator of CUE, with increasing $\mathrm{C}$ and/or decreasing $\mathrm{N}$ and $\mathrm{P}$ availability resulting in declining CUE (Manzoni et al. 2012, Sinsabaugh et al. 2013). CUE declines with declining $\mathrm{C}$ quality (increasing proportion of refractory $\mathrm{C}$ ), and is inversely related to soil moisture and $\mathrm{O}_{2}$ concentration in the substrate (Manzoni et al. 2012, Sinsabaugh et al. 2013).

The role of microbial enzymes in organic matter decomposition is widely recognized, and several models have been proposed to capture the interactions between enzyme activity, available $\mathrm{C}$ and $\mathrm{N}$, and CUE (Sinsabaugh \& Moorhead 1994, Schimel \& Weintraub 2003, Moorhead et al. 2012). The models have demonstrated that both $\mathrm{C}$ quality and the stoichiometric balance between $\mathrm{C}$ and $\mathrm{N}$ availability regulate microbial production and organic matter decomposition. Herein, we examined the relationships of DHA and EEA with $\mathrm{C}, \mathrm{N}$, and $\mathrm{P}$ from the sediments of the hypoxic region of the Louisiana continental shelf.

The objectives of this paper were to (1) explore microbial respiration (DHA) and EEA in sediment cores from the Louisiana shelf of the northern GOM, (2) investigate changes in DHA and EEA with sediment depth and across the 4 zones of similarity (sensu Lehrter et al. 2012), and (3) compare microbial DHA and EEA to sediment $C, N$, and $P$ availability. The results indicated that DHA and EEA, and hence CUE and modeled respiration $\left(R_{\mathrm{m}}\right)$, were sensi- tive to spatial patterns of $\mathrm{C}, \mathrm{N}$, and $\mathrm{P}$ as dictated by proximity to the Mississippi and Atchafalaya Rivers. Thus, ecoenzyme activity may be a good proxy for evaluating system responses to eutrophication, as well as linking changes in $\mathrm{C}, \mathrm{N}$, and $\mathrm{P}$ loading to alterations of sediment carbon cycling.

\section{MATERIALS AND METHODS}

\section{Site selection}

Sediment samples from the northern GOM hypoxic zone were collected from 41 cores along the Louisiana continental shelf during 6 cruises in 2006, 2007, and 2010 (Fig. 1). The GOM survey design included sites representative of the Mississippi River plume, near plume, far plume, and in-shore zones of similarity (Lehrter et al. 2012). These 4 zones of the Louisiana Shelf were hypothesized to have differing degrees of hypoxia related to proximity to freshwater influence and depth. Zone 1 (2 sites sampled in April 2006, June 2006, and September 2006) represented the Mississippi and Atchafalaya River plumes. Zone 2 (2 sites in April 2006, April 2007, and August 2007; 4 sites in June 2006 and September 2006; 5 sites in August 2010) represented the near plume areas with depths between 10 and $30 \mathrm{~m}$. Zone 3 (2 sites in April 2007 and August 2007; 4 sites in August 2010) represented the far plume region and with depths greater than 30 m. Zone 4 (3 sites in April 2007 and August

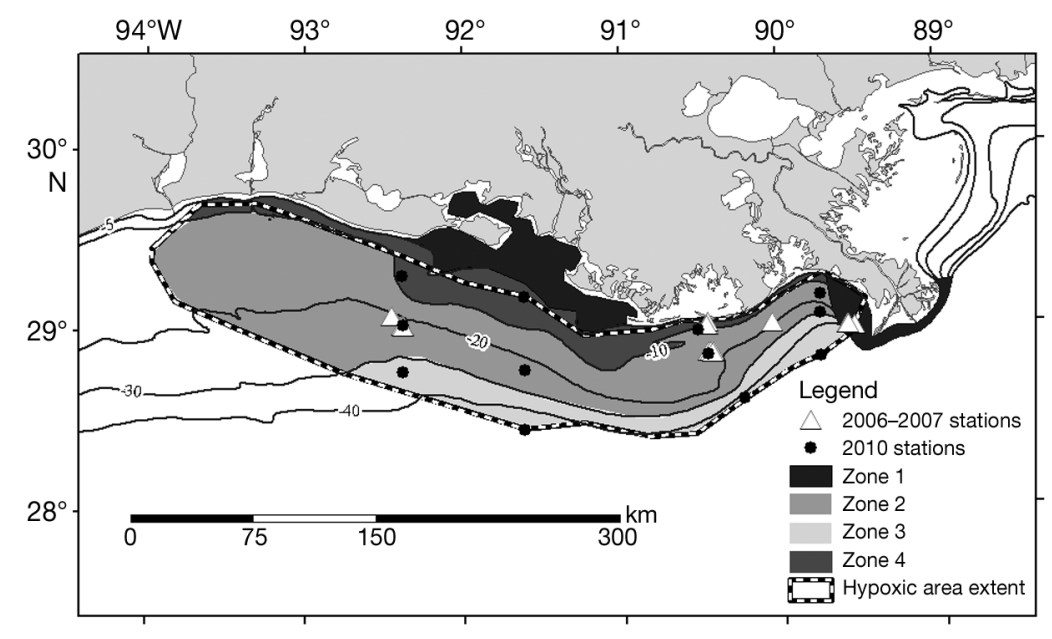

Fig. 1. Northern Gulf of Mexico hypoxic zone, the 4 zones of similarity (sensu Lehrter et al. 2012), and sampling locations during the 2006-2007 and 2010 cruises. Twenty-nine sites were visited during the 2006-2007 cruises (triangles; some site locations are obscured by the triangles); 12 sites were sampled during the 2010 cruises (dots). The distribution of sampling effort between years and among the zones is presented in the 'Materials and methods' section 
2010; 2 sites in August 2007) represented the shallow inshore region adjacent to the coast (Fig. 1). Lehrter et al. (2012) report average zone water chemistries and sediment characteristics for 6 cruises between 2005 and 2007, which include our 2006-2007 cruises.

To evaluate potential impacts of $\mathrm{O}_{2}$ on ecoenzyme activities, we calculated the oxygen penetration depth (OPD; Cai \& Sayles 1996) as:

$$
\mathrm{OPD}=2 \phi \mathrm{Ds}\left(\left[\mathrm{O}_{2}\right]_{\mathrm{BW}} / \mathrm{SOD}\right)
$$

where $\phi$ is sediment porosity, Ds is the diffusion coefficient of $\mathrm{O}_{2}$ at $25^{\circ} \mathrm{C}\left(2.29 \mathrm{e}^{-5} \mathrm{~cm}^{2} \mathrm{~s}^{-1}\right),\left[\mathrm{O}_{2}\right]_{\mathrm{BW}}$ is the bottom-water $\mathrm{O}_{2}$ concentration $\left(\mathrm{mmol} \mathrm{m}^{-3}\right)$, and SOD is the sediment oxygen demand $\left(\mathrm{mmol} \mathrm{O}_{2} \mathrm{~m}^{-2} \mathrm{~d}^{-1}\right)$.

\section{Sediment collection and analyses}

Sediment cores were collected using a hydraulically-dampened multi-core (Ocean Instruments MC400, Ocean Instruments). The multi-core collected 4 replicate cores, 3 of which were used for measurements of sediment-water fluxes of $\mathrm{C}$ and nutrients (Lehrter et al. 2012). The remaining core was used for chemical analyses. Core lengths ranged from 16 to $20 \mathrm{~cm}$, except for the August 2010 cruise, when only surface $(0$ to $4 \mathrm{~cm})$ sediment was collected. The chemical analysis core was sectioned ( $2 \mathrm{~cm}$ intervals) on the ship, frozen, and returned to the laboratory for analyses of total carbon (TC), nitrogen (TN), phosphorus (TP), DHA, and EEA. Previous studies (Broberg 1985, Lee et al. 2007, DeForest 2009, Burns et al. 2013), and tests in our lab revealed no consistent differences between samples that had been processed fresh, stored refrigerated $\left(4^{\circ} \mathrm{C}\right)$, or stored frozen $\left(-20^{\circ} \mathrm{C}\right)$. As has been our practice for large-scale aquatic surveys (Hill et al. 2006, 2010, 2012), all samples were frozen as soon as possible after collection, and stored frozen until analyzed, thus yielding a sample that has been consistently stored and processed, one that provides a snapshot of microbial DHA and EEA at the time of sampling, and one that is comparable to a large body of published values.

Upon thawing, sediment water content was determined gravimetrically and percent solids were used to calculate available $\mathrm{C}, \mathrm{N}$, and $\mathrm{P}$ content on a dry weight (DW) basis. Sediment samples were dried and ground for nutrient analysis. Sediment TC and TN were determined by the combustion method using an elemental analyzer (Model 1112EA, Carla Erba Instrumentazione). Samples for sediment TP were first digested in reagent grade concentrated $\mathrm{HNO}_{3}$ using a microwave digester (Anton Paar Multiwave, Anton
Paar), neutralized with $10 \mathrm{ml} \mathrm{NaOH}$, diluted to $100 \mathrm{ml}$ with deionized water, and analyzed by the molybdate-ascorbic acid method (APHA 1998).

\section{Microbial respiration and extracellular enzyme activity}

Sediments collected from each site were thawed, mixed, and analyzed for DHA and EEA. Duplicate samples for DHA analysis were mixed with $2.5 \mathrm{ml}$ of sterile $\mathrm{H}_{2} \mathrm{O}$ and $1 \mathrm{ml}$ of $0.75 \% 2$-(p-iodophenyl)-3( $p$-nitrophenyl)-5-phenyl tetrazolium chloride (INT) standard, sealed, agitated, and incubated (dark, $27^{\circ} \mathrm{C}$ ) for $3 \mathrm{~h}$. The resulting substrate concentration $(0.16 \%$ by sediment volume) was within the range deemed saturating, but not toxic, for sediment and biofilm samples (Broberg 1985, Blenkinsopp \& Lock 1990). Duplicate analyses without a killed control were deemed acceptable based on our previous experience (Hill et al. 2002, 2010, 2012) that indicated variance among replicates was much less than the variance among sites. Incubations were terminated by adding $8 \mathrm{ml}$ of methanol. Samples were centrifuged $(2000 \times g)$ for 5 min and the supernatant analyzed for absorbance (428 nm) using a Perkin Elmer UV (Model Lambda 20) spectrophotometer (Perkin Elmer Life and Analytical Sciences). Sample absorbance was compared to a standard INT curve (prepared for each sample batch) and normalized by incubation time and sediment DW to calculate DHA activity (nmol h$\left.{ }^{-1} \mathrm{~g}^{-1} \mathrm{DW}\right)$.

Carbon acquisition was measured as $\beta$-D-glucosidase activity (BG: EC 3.2.1.21); nitrogen acquisition was measured as the sum of $\beta$-N-acetylglucosaminidase (NAG: EC 3.2.1.50) and L-leucine aminopeptidase activity (LAP: EC 3.4.11.1); phosphorus acquisition was measured as acid phosphatase (AP: EC 3.1.3.2), and sulfur acquisition was measured as aryl sulfatase (SULF: EC 3.1.6.1) activity. The glycosidase, aminidase, aminopeptidase, phosphatase, and sulfatase assays used substrates linked to either methylumbelliferyl (MUB) or methyl-coumarin (MCM) residues (Sigma-Aldrich). All EEA assays used the microplate protocols originally developed by Sinsabaugh and colleagues (Sinsabaugh et al. 1997, Foreman et al. 1998, Sinsabaugh \& Foreman 2001), as modified by Hill et al. (2010). Substrate stocks and reference solutions were prepared in sterile deionized water. Stock solutions containing $200 \mu \mathrm{mol}$ of substrate $\mathrm{l}^{-1}$ were added to $200 \mu \mathrm{l}$ of sediment, resulting in saturating concentrations when diluted for each assay with sterile deionized water and acetate 
buffer (pH 5). Enzyme assays included quadruplicate analyses for each enzyme, positive and negative controls, and reference standards. Numerous assays were conducted to determine the best reaction times, and these many repetitions assured us of the result. Quenching, the decrease of fluorescent emissions caused by the interactions of enzyme substrates with non-reactant chemicals in the assays, was estimated by comparing the fluorescence of the supernatant of standards mixed with sediment slurries (sediment + buffer) to that of the standard solution mixed with buffer. We incubated the microplates for various times, depending on substrates, at $20^{\circ} \mathrm{C}$ for MUBlinked substrates and at $30^{\circ} \mathrm{C}$ for MCM-linked substrates. Fluorescence was measured using a fluorometer (Model FLX800T, BioTek Instruments) with an excitation wavelength of $350 \mathrm{~nm}$ and an emission wavelength of $450 \mathrm{~nm}$. We reported extracellular enzyme activity as substrate accumulated per unit of sediment over time, adjusted for emission coefficients calculated from standards, and corrected for quenching (nmol h$\left.{ }^{-1} \mathrm{~g}^{-1} \mathrm{DW}\right)$.

We used microbial enzyme activity and stoichiometry to determine the nutrient limitation and CUE for each sample analyzed. Nutrient limitation was based on deviations from expected ratios of $\mathrm{C}-, \mathrm{N}-$, and $\mathrm{P}-$ acquiring enzyme activities (Sinsabaugh \& Moorhead 1994, Sinsabaugh et al. 2009, Hill et al. 2012). CUE was predicted as a saturating function based on $\mathrm{N}$ and $\mathrm{P}$ supply relative to $\mathrm{C}$ availability (Sinsabaugh et al. 2013).

Organic $\mathrm{C}$ decomposition rate $\left(M, \% \mathrm{~d}^{-1}\right)$ was modeled using a microbial enzyme allocation model (Sinsabaugh \& Moorhead 1994). We substituted CUE, as calculated by Sinsabaugh et al. (2013, their Eq. 4), for the static enzyme degradation efficiency $\left(k_{\mathrm{c}}=0.2 ;\right.$ Sinsabaugh \& Moorhead 1994). Respiration

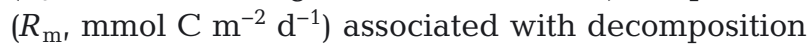
was estimated as the product of the organic $\mathrm{C}$ pool $\left(\mathrm{mmol} \mathrm{kg}^{-1}\right), M$, and the bulk density $\left(\mathrm{kg} \mathrm{m}^{-3}\right)$ of the sediment.

\section{Statistical analyses}

We compiled descriptive statistics (mean \pm standard error of the mean) for sediment $\mathrm{C}, \mathrm{N}$, and $\mathrm{P}$ concentrations, and microbial DHA and EEA related to $\mathrm{C}, \mathrm{N}, \mathrm{P}$, and $\mathrm{S}$ acquisition. We tested the differences between cruises, zones of similarity, sediment depth, and their interactions using a Type III General Linear Model of an unbalanced, nested sampling design. Correlations between sediment chemistry and micro- bial activity were evaluated by Spearman rank correlation (r) to avoid problems associated with nonnormal data distribution. Relationships between DHA, EEA, and $R_{\mathrm{m}}$ were analyzed using ordinary least squares regression of natural log-transformed sample means. All analyses were done using SAS for Windows, release 9.2 (SAS Institute).

\section{Structural equation modeling}

We used structural equation modeling (SEM) to assess the strengths of the interactions between sediment chemistry, EEA, and DHA. SEM is a form of general linear and multivariate modeling that uses empirical data and theoretical models to facilitate the investigation of explicit connections between stressor and response variables (Grace et al. 2010). We described these relationships as a series of linked, structural equations, and tested the validity of those equations using the PROC CALIS procedure in SAS. The resulting correlation matrix was tested for goodness of fit ( $\chi^{2}$ test), and the multiple regression model that emerged from that analysis was used to estimate the relative strengths of the relationships described in the conceptual model. All data were log-transformed to meet the assumptions of multivariate normality.

\section{RESULTS}

OPD was calculated from data presented in Lehrter et al. (2012) for $\phi,\left[\mathrm{O}_{2}\right]_{\mathrm{BW}}$, and SOD at the same sites as those sampled in this study. The average OPDs ranged from $1.32 \mathrm{~mm}$ in Zone 4 to $2.92 \mathrm{~mm}$ in Zone 2 (Table 1). Thus, only the surface samples for ecoenzyme analyses may have been impacted by oxygen in the sediments.

We compared TC, TN, and TP concentrations at $2 \mathrm{~cm}$ increments along the 16 to $20 \mathrm{~cm}$ depth of the sediment cores collected from the GOM sampling locations (Fig. 2). Samples from each of the 6 cruises were significantly different, but since the goal of the project was to characterize the sediment chemistryEEA relationships within the zones of similarity, and there were no Cruise $\times$ Zone interaction effects, except for TN (Table 2), the data from the 6 cruises were combined (Table 1). Similarly, only TN exhibited a significant core depth effect. Thus, samples from the 6 cruises were combined to give average sediment chemistries for the 4 zones of similarity. Microbial DHA and EEA, with the exception of [NAG + LAP] and SULF, declined with increasing 
Table 1. Mean $( \pm \mathrm{SE})$ values for oxygen penetration depth $(\mathrm{OPD}, \mathrm{mm})$, sediment chemistry (TC, TN, TP, mmol kg-1), microbial respiration (DHA, nmol INT h${ }^{-1}$ $\left.\mathrm{g}^{-1} \mathrm{DW}\right)$, extracellular enzyme activity (BG, [NAG+LAP], $\mathrm{AP}, \mathrm{nmol} \mathrm{h} \mathrm{h}^{-1} \mathrm{~g}^{-1} \mathrm{DW}$ ), carbon use efficiency (CUE), organic C decomposition rate $\left(M, \% \mathrm{~d}^{-1}\right)$, and

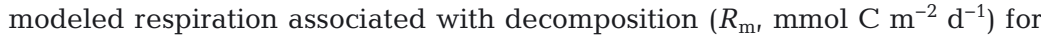
sediments from the 4 zones of the northern Gulf of Mexico hypoxic zone

\begin{tabular}{|lcccc|}
\hline \multicolumn{1}{|c}{$\begin{array}{c}\text { Zone 1 } \\
(\mathrm{n}=25)\end{array}$} & $\begin{array}{c}\text { Zone 2 } \\
(\mathrm{n}=86)\end{array}$ & $\begin{array}{c}\text { Zone } 3 \\
(\mathrm{n}=38)\end{array}$ & $\begin{array}{c}\text { Zone 4 } \\
(\mathrm{n}=43)\end{array}$ \\
\hline $\begin{array}{l}\text { Oxygen penetration depth } \\
\text { OPD }\end{array}$ & $2.67(0.16)$ & $2.92(0.24)$ & $2.35(0.06)$ & $1.32(0.07)$ \\
Sediment chemistry & & & \\
TC & $632(35.8)$ & $1114(50.7)$ & $836(30.6)$ & $681(44.7)$ \\
TN & $32.6(490)$ & $36.8(3.03)$ & $21.8(2.67)$ & $21.8(3.00)$ \\
TP & $40.9(2.16)$ & $36.7(1.43)$ & $28.1(1.98)$ & $30.0(1.80)$ \\
Microbial enzyme activity & & & \\
DHA & $2508(209)$ & $1856(154)$ & $817(133)$ & $703(65.5)$ \\
BG & $28.2(3.48)$ & $46.9(4.98)$ & $44.3(8.21)$ & $23.9(3.32)$ \\
[NAG + LAP] & $66.2(11.2)$ & $37.1(6.52)$ & $19.2(13.1)$ & $7.08(1.17)$ \\
AP & $33.8(4.16)$ & $69.6(8.57)$ & $85.9(14.2)$ & $52.3(9.07)$ \\
Decomposition model & & & \\
CUE & $0.56(0.006)$ & $0.50(0.010)$ & $0.33(0.018)$ & $0.42(0.015)$ \\
$M$ & $0.16(0.014)$ & $0.16(0.008)$ & $0.09(0.008)$ & $0.07(0.007)$ \\
$R_{\mathrm{m}}$ & $1764(212)$ & $5497(584)$ & $1462(249)$ & $766(119)$ \\
\hline
\end{tabular}

core depth (Table 2, Fig. 3a-d), as did the organic $\mathrm{C}$ decomposition rate $(M$; Table 1, Fig. 4b); CUE and modeled respiration ( $R_{\mathrm{m} i}$ Table 2 , Fig. $\left.4 \mathrm{a}, \mathrm{c}\right)$ did not change with depth.

We also compared TC, TN, and TP concentrations (averaged for each core and across cruises) between the 4 zones of similarity in the northern GOM hypoxic zone. Sediment TC, $\mathrm{TN}$, and TP all exhibited significant differences between zones (Tables 1 \& 2). Microbial DHA, EEA with the exception of [NAG + LAP], CUE, $M$, and $R_{\mathrm{m}}$ were also significantly different between the zones of similarity (Table 2).

Sediment TC, TN, and TP, over all cruises, zones, and depths, were all positively correlated with each other ( $\mathrm{r}=0.18-0.62 ;$ Table 3$)$. DHA was positively correlated with EEA and
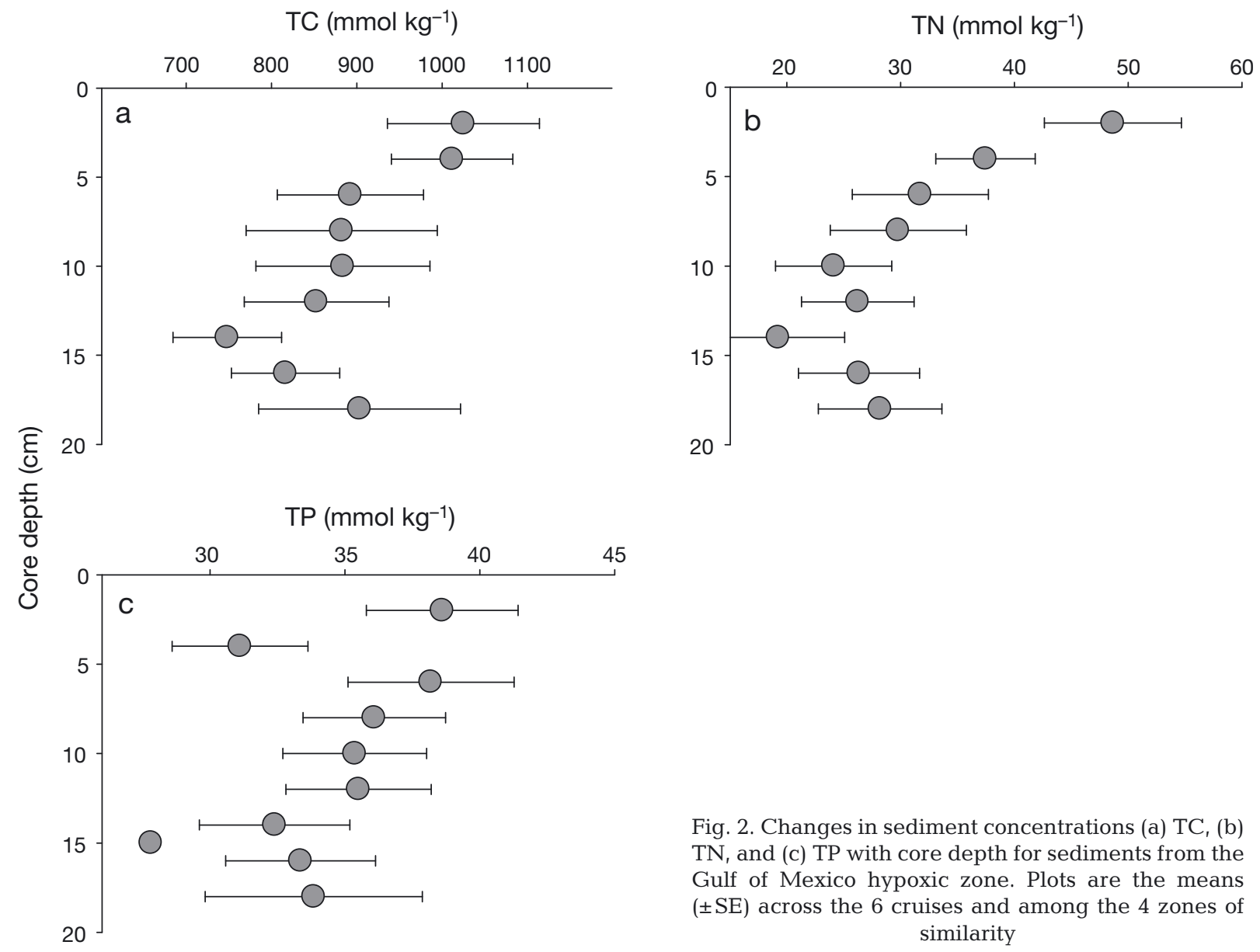

Fig. 2. Changes in sediment concentrations (a) TC, (b) TN, and (c) TP with core depth for sediments from the Gulf of Mexico hypoxic zone. Plots are the means $( \pm \mathrm{SE})$ across the 6 cruises and among the 4 zones of similarity 
Table 2. Type III General Linear Model analysis of an unbalanced, nested sampling design for sediment $\mathrm{C}, \mathrm{N}$, and $\mathrm{P}$, microbial respiration (DHA), microbial enzyme activities $(\mathrm{BG},[\mathrm{NAG}+\mathrm{LAP}], \mathrm{AP}$, and SULF), modeled carbon use efficiency (CUE), organic $C$ decomposition $(M)$, and associated respiration $\left(R_{\mathrm{m}}\right)$ for sediments from the northern Gulf of Mexico. All values were natural log-transformed prior to analysis. Significant cruise, zone, core depth, and interaction effects are indicate by bold $p$-values

\begin{tabular}{|c|c|c|c|c|}
\hline Variable & Effects & df & $F$ & $\mathrm{p}$ \\
\hline \multirow[t]{4}{*}{$\mathrm{TC}$} & Cruise & 5 & 5.25 & 0.0002 \\
\hline & Zone & 3 & 18.0 & $<0.0001$ \\
\hline & Core depth & 9 & 0.95 & 0.4854 \\
\hline & $\begin{array}{l}\text { Core depth } \times \\
\quad(\text { Cruise } \times \text { Zone })\end{array}$ & 90 & 0.97 & 0.5624 \\
\hline \multirow[t]{4}{*}{$\mathrm{TN}$} & Cruise & 5 & 27.9 & $<0.0001$ \\
\hline & Zone & 3 & 3.82 & 0.0114 \\
\hline & Core depth & 9 & 3.34 & 0.0010 \\
\hline & $\begin{array}{l}\text { Core depth } \times \\
\quad(\text { Cruise } \times \text { Zone })\end{array}$ & 90 & 1.37 & 0.0472 \\
\hline \multirow[t]{4}{*}{$\mathrm{TP}$} & Cruise & 5 & 275 & $<0.0001$ \\
\hline & Zone & 3 & 6.96 & 0.0002 \\
\hline & Core depth & 9 & 1.58 & 0.1257 \\
\hline & $\begin{array}{l}\text { Core depth } \times \\
\quad(\text { Cruise } \times \text { Zone })\end{array}$ & 90 & 1.08 & 0.3468 \\
\hline \multirow[t]{4}{*}{ DHA } & Cruise & 5 & 15.5 & $<0.0001$ \\
\hline & Zone & 3 & 3.09 & 0.0293 \\
\hline & Core depth & 9 & 3.21 & 0.0014 \\
\hline & $\begin{array}{l}\text { Core depth } \times \\
\quad(\text { Cruise } \times \text { Zone })\end{array}$ & 90 & 0.90 & 0.7065 \\
\hline \multirow[t]{4}{*}{ BG } & Cruise & 5 & 10.5 & $<0.0001$ \\
\hline & Zone & 3 & 6.47 & 0.0004 \\
\hline & Core depth & 9 & 5.47 & $<0.0001$ \\
\hline & $\begin{array}{l}\text { Core depth } \times \\
\quad(\text { Cruise } \times \text { Zone })\end{array}$ & 90 & 0.95 & 0.5955 \\
\hline \multirow{4}{*}{$\begin{array}{l}{[\mathrm{NAG}+} \\
\text { LAP }]\end{array}$} & Cruise & 5 & 22.7 & $<0.0001$ \\
\hline & Zone & 3 & 1.38 & 0.2655 \\
\hline & Core depth & 9 & 1.60 & 0.1557 \\
\hline & $\begin{array}{l}\text { Core depth } \times \\
\quad(\text { Cruise } \times \text { Zone })\end{array}$ & 46 & 1.29 & 0.2262 \\
\hline \multirow[t]{4}{*}{$\mathrm{AP}$} & Cruise & 5 & 10.6 & $<0.0001$ \\
\hline & Zone & 3 & 9.72 & $<0.0001$ \\
\hline & Core depth & 9 & 9.44 & $<0.0001$ \\
\hline & $\begin{array}{l}\text { Core depth } \times \\
\quad(\text { Cruise } \times \text { Zone })\end{array}$ & 90 & 1.37 & 0.0453 \\
\hline \multirow[t]{4}{*}{ SULF } & Cruise & 5 & 21.5 & $<0.0001$ \\
\hline & Zone & 3 & 26.3 & $<0.0001$ \\
\hline & Core depth & 9 & 1.19 & 0.3059 \\
\hline & $\begin{array}{l}\text { Core depth } \times \\
\quad(\text { Cruise } \times \text { Zone })\end{array}$ & 90 & 1.08 & 0.3358 \\
\hline \multirow[t]{4}{*}{ CUE } & Cruise & 5 & 7.91 & $<0.0001$ \\
\hline & Zone & 3 & 12.9 & $<0.0001$ \\
\hline & Core depth & 8 & 1.08 & 0.3806 \\
\hline & $\begin{array}{l}\text { Core depth } \times \\
\quad(\text { Cruise } \times \text { Zone })\end{array}$ & 76 & 1.07 & 0.3670 \\
\hline \multirow[t]{4}{*}{$M$} & Cruise & 5 & 8.30 & $<0.0001$ \\
\hline & Zone & 3 & 7.72 & 0.0001 \\
\hline & Core depth & 8 & 2.84 & 0.0069 \\
\hline & $\begin{array}{l}\text { Core depth } \times \\
\quad(\text { Cruise } \times \text { Zone })\end{array}$ & 76 & 1.03 & 0.4467 \\
\hline \multirow[t]{4}{*}{$R_{\mathrm{m}}$} & Cruise & 5 & 12.3 & $<0.0001$ \\
\hline & Zone & 3 & 13.2 & $<0.0001$ \\
\hline & Core depth & 8 & 1.48 & 0.1742 \\
\hline & $\begin{array}{l}\text { Core depth } \times \\
\quad(\text { Cruise } \times \text { Zone })\end{array}$ & 76 & 1.34 & 0.0850 \\
\hline
\end{tabular}

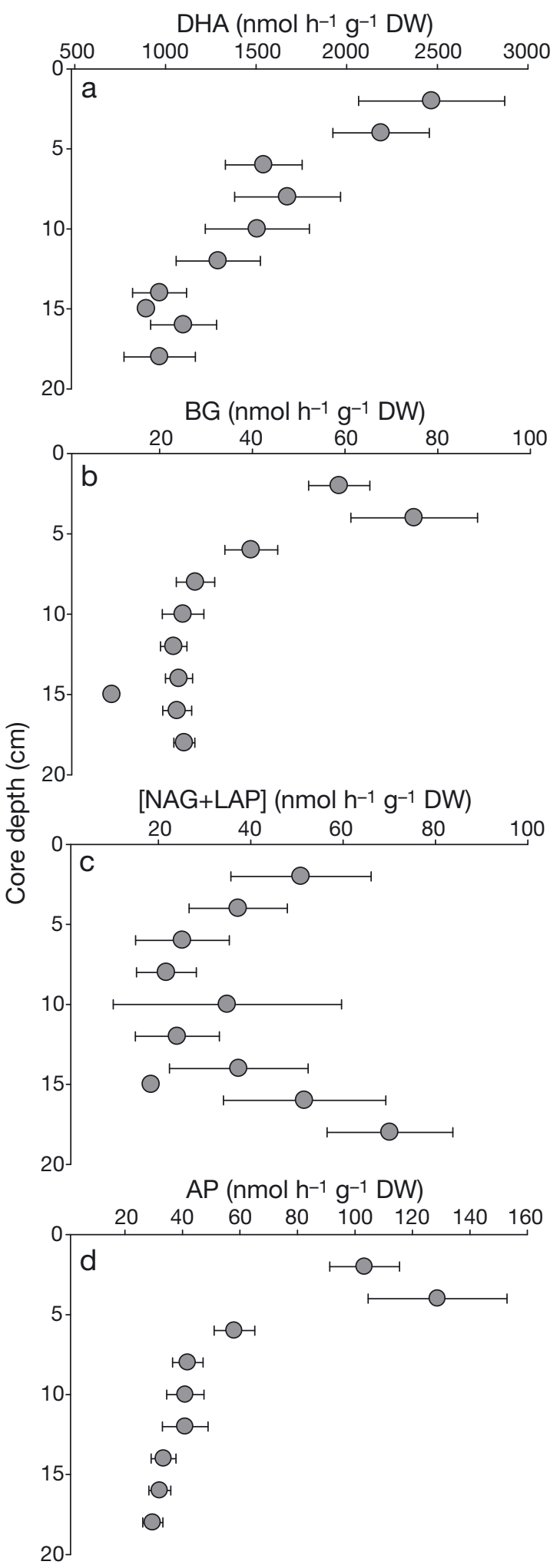

Fig. 3. Changes in microbial respiration (DHA) and extracellular enzyme activity related to C (BG), N [NAG + LAP], and $\mathrm{P}$ (AP) acquisition with core depth for sediments from the Gulf of Mexico hypoxic zone. Plots are the means $( \pm \mathrm{SE})$ across the 6 cruises and among the 4 zones of similarity 

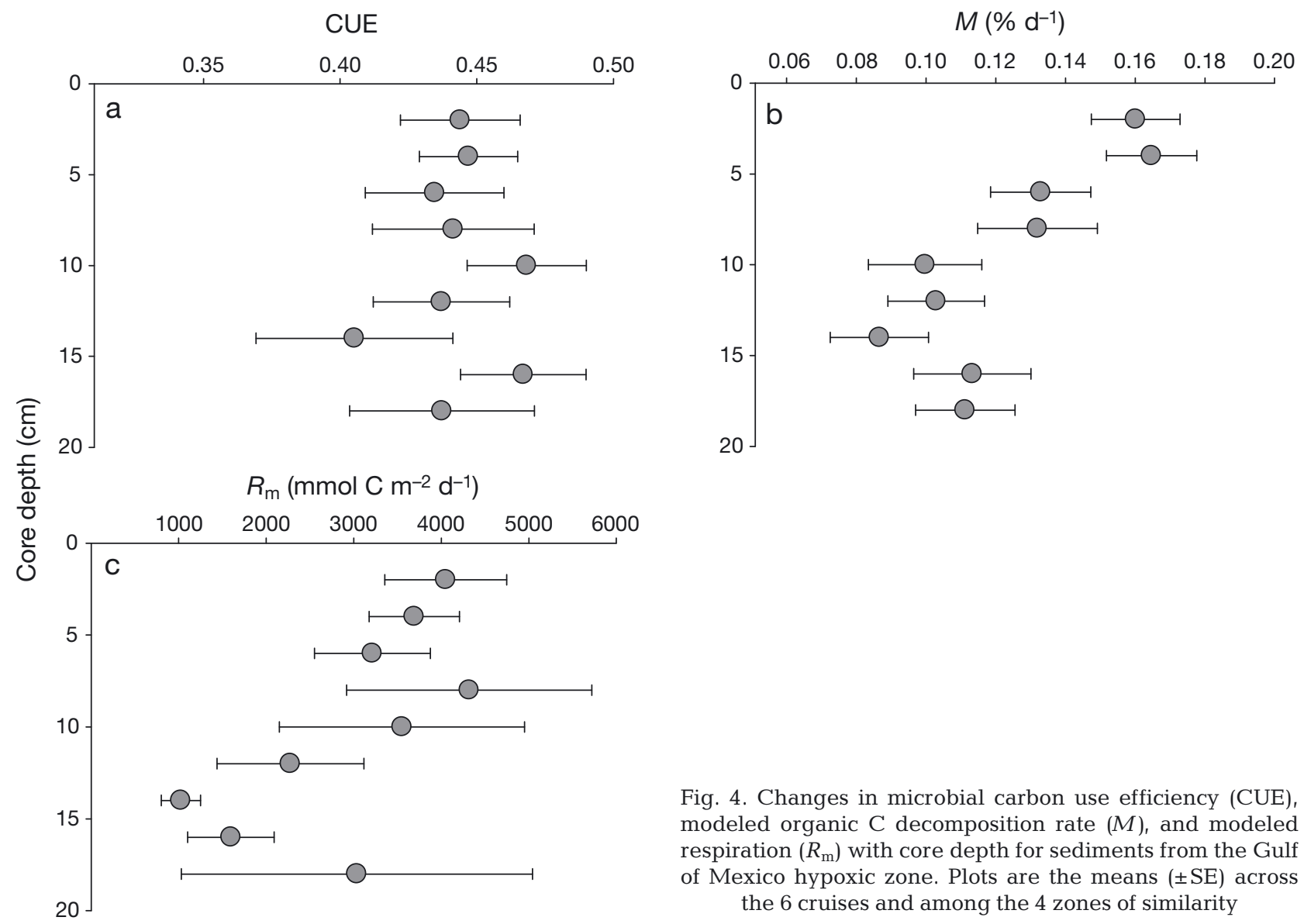

Fig. 4. Changes in microbial carbon use efficiency (CUE), modeled organic $\mathrm{C}$ decomposition rate $(M)$, and modeled respiration $\left(R_{\mathrm{m}}\right)$ with core depth for sediments from the Gulf of Mexico hypoxic zone. Plots are the means $( \pm \mathrm{SE})$ across the 6 cruises and among the 4 zones of similarity

Table 3. Spearman correlation between sediment chemistry (TC, TN, and TP), microbial respiration (DHA) and microbial extracellular enzyme activity (BG, [NAG+LAP], AP, SULF), carbon use efficiency (CUE), modeled decomposition rate ( $M$ ) and respiration $\left(R_{\mathrm{m}}\right)$ for sediments from the northern Gulf of Mexico hypoxic zone. All correlations are significant at the $\mathrm{p}<0.05$ level unless indicated as not significant (ns). Sample sizes for each correlation are given in parentheses below the correlation coefficient

\begin{tabular}{|c|c|c|c|c|c|c|c|c|c|c|}
\hline & $\mathrm{TN}$ & $\mathrm{TP}$ & DHA & BG & {$[\mathrm{NAG}+\mathrm{LAP}]$} & $\mathrm{AP}$ & SULF & CUE & $M$ & $R_{\mathrm{m}}$ \\
\hline $\mathrm{TC}$ & $\begin{array}{c}0.62 \\
(250)\end{array}$ & $\begin{array}{c}0.18 \\
(248)\end{array}$ & $\begin{array}{c}0.22 \\
(250)\end{array}$ & $\begin{array}{c}0.60 \\
(249)\end{array}$ & $\begin{array}{l}0.46 \\
(97)\end{array}$ & $\begin{array}{c}0.58 \\
(249)\end{array}$ & $\begin{array}{c}0.56 \\
(248)\end{array}$ & $\begin{array}{c}\text { ns } \\
(192)\end{array}$ & $\begin{array}{c}0.49 \\
(192)\end{array}$ & $\begin{array}{c}0.90 \\
(192)\end{array}$ \\
\hline $\mathrm{TN}$ & & $\begin{array}{c}0.37 \\
(248)\end{array}$ & $\begin{array}{c}0.27 \\
(250)\end{array}$ & $\begin{array}{c}0.58 \\
(249)\end{array}$ & $\begin{array}{l}0.64 \\
(97)\end{array}$ & $\begin{array}{c}0.50 \\
(249)\end{array}$ & $\begin{array}{c}0.43 \\
(248)\end{array}$ & $\begin{array}{c}0.43 \\
(192)\end{array}$ & $\begin{array}{c}0.60 \\
(192)\end{array}$ & $\begin{array}{c}0.67 \\
(192)\end{array}$ \\
\hline $\mathrm{TP}$ & & & $\begin{array}{c}0.33 \\
(248)\end{array}$ & $\begin{array}{c}\text { ns } \\
(247)\end{array}$ & $\begin{array}{l}0.62 \\
(96)\end{array}$ & $\begin{array}{c}\mathrm{ns} \\
(247)\end{array}$ & $\begin{array}{c}0.17 \\
(246)\end{array}$ & $\begin{array}{c}0.46 \\
(192)\end{array}$ & $\begin{array}{c}0.24 \\
(192)\end{array}$ & $\begin{array}{c}0.17 \\
(192)\end{array}$ \\
\hline \multirow[t]{2}{*}{ DHA } & & & & 0.30 & 0.65 & 0.17 & 0.42 & 0.58 & 0.61 & 0.50 \\
\hline & & & & $(249)$ & $(97)$ & $(249)$ & $(248)$ & $(192)$ & $(192)$ & (192) \\
\hline $\mathrm{BG}$ & & & & & $\begin{array}{l}0.56 \\
(97)\end{array}$ & $\begin{array}{c}0.76 \\
(249)\end{array}$ & $\begin{array}{c}0.63 \\
(247)\end{array}$ & $\begin{array}{c}\text { ns } \\
(192)\end{array}$ & $\begin{array}{c}0.85 \\
(192)\end{array}$ & $\begin{array}{c}0.76 \\
(192)\end{array}$ \\
\hline \multirow[t]{2}{*}[\mathrm{NAG}+\mathrm{LAP}]{} & & & & & & 0.34 & 0.58 & 0.85 & 0.70 & 0.61 \\
\hline & & & & & & (249) & $(96)$ & $(74)$ & $(74)$ & $(74)$ \\
\hline \multirow[t]{2}{*}{$\mathrm{AP}$} & & & & & & & 0.56 & ns & 0.53 & 0.60 \\
\hline & & & & & & & $(247)$ & (192) & (192) & (192) \\
\hline SULF & & & & & & & & $\begin{array}{c}0.24 \\
(190)\end{array}$ & $\begin{array}{c}0.69 \\
(190)\end{array}$ & $\begin{array}{c}0.67 \\
(190)\end{array}$ \\
\hline CUE & & & & & & & & & $\begin{array}{c}0.33 \\
(192)\end{array}$ & $\begin{array}{c}0.16 \\
(192)\end{array}$ \\
\hline$M$ & & & & & & & & & & $\begin{array}{c}0.79 \\
(192)\end{array}$ \\
\hline
\end{tabular}



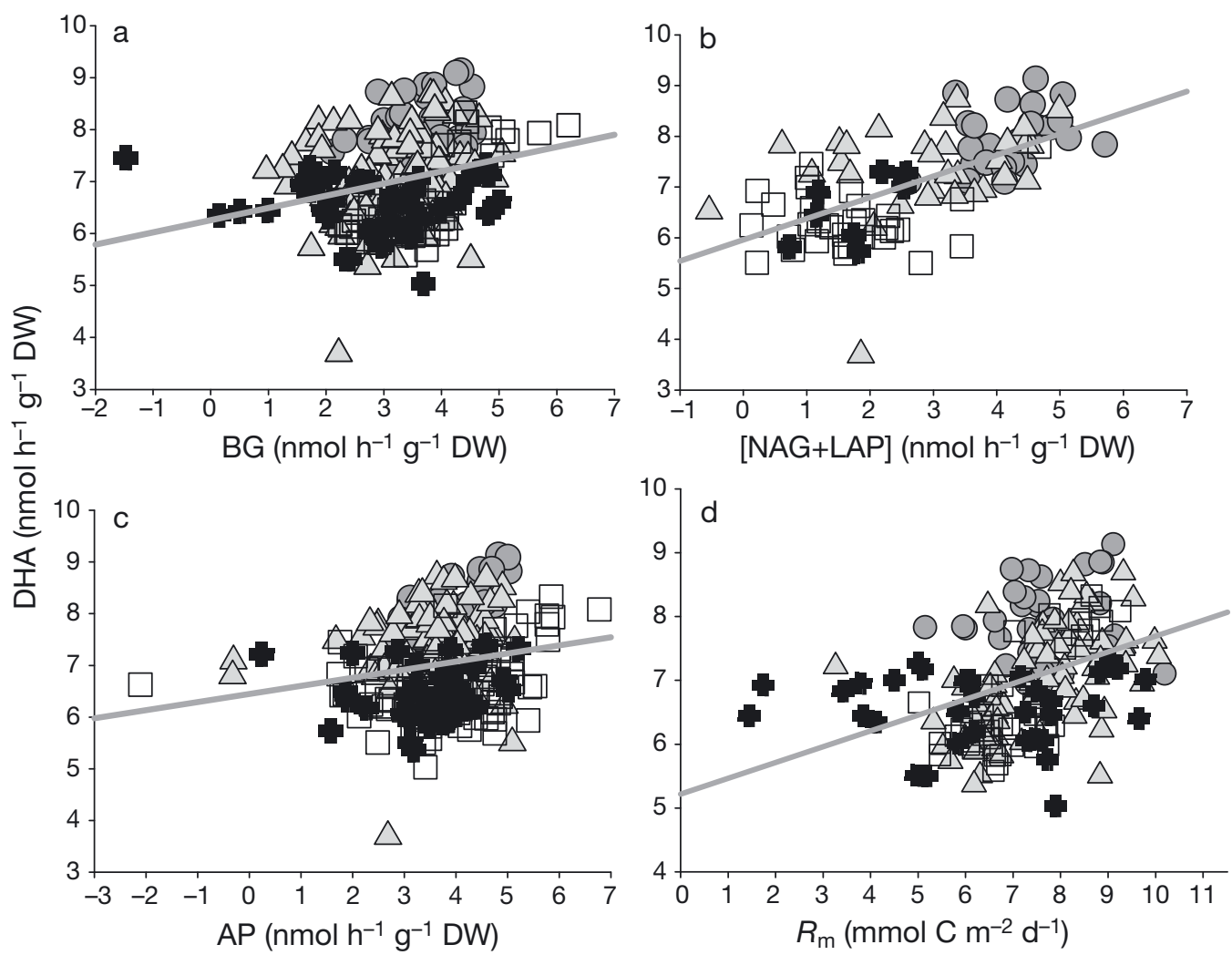

Fig. 5. Ordinary least squares regression plots for microbial respiration (DHA) as a function of BG, [NAG + LAP], AP activities, and $R_{\mathrm{m}}$. (a) $\ln \mathrm{DHA}=0.27$ (ln BG) $+6.13, \mathrm{r}^{2}=0.07, \mathrm{p}<0.0001$; (b) $\left.\ln \mathrm{DHA}=0.47(\ln \mathrm{NAG}+\mathrm{LAP}]\right)+5.75, \mathrm{r}^{2}=0.41, \mathrm{p}<0.0001 ;(\mathrm{c})$ $\ln \mathrm{DHA}=0.18(\ln \mathrm{AP})+6.35, \mathrm{r}^{2}=0.04, \mathrm{p}=0.0012 ;(\mathrm{d}) \ln \mathrm{DHA}=0.25\left(\ln R_{\mathrm{m}}\right)+5.22, \mathrm{r}^{2}=0.17, \mathrm{p}<0.0001$. Regression lines are plotted only for significant $(\mathrm{p}<0.05)$ regression models. Zone $1=$ dark gray circles; Zone $2=$ light gray triangles; Zone $3=$ black crosses; Zone 4 = open boxes

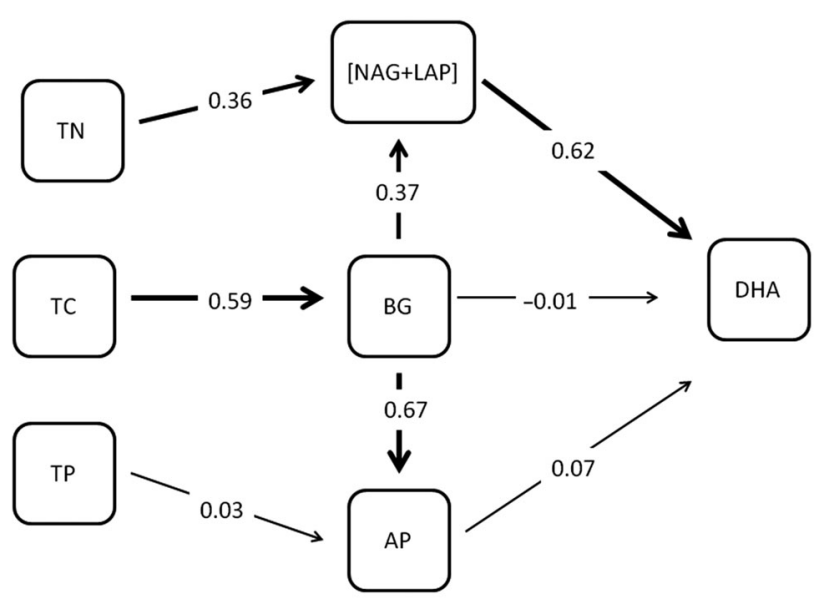

Fig. 6. Structural equation model describing the association between sediment chemistry (TC, TN, and TP), EEA (BG, $[\mathrm{NAG}+\mathrm{LAP}]$, and AP), and DHA. Boxes are variables in the model and lines represent the paths connecting variables. The numbers associated with each line are the relative strengths of the connections based on standardized correlations based on maximum likelihood estimation. The model explained $46 \%$ of the variance in log-transformed sediment respiration (DHA). Model fit: $\chi^{2}=42, \mathrm{df}=10, \mathrm{p}<0.0001$. All variables were log-transformed
$R_{\mathrm{m}}$ (0.17-0.65; Table 3, Fig. 5), and all of the EEA were positively correlated with all other EEA (0.37-0.76; Table 3). DHA (0.23-0.33), [NAG + LAP] (0.46-0.64), and SULF (0.17-0.56) were positively correlated with TC, TN, and TP; BG (0.58-0.60) and AP (0.50-0.58) were correlated only with TC and TN (Table 3). CUE was positively correlated with TN and TP, and with DHA, [NAG + LAP], and SULF (Table 3); $M$ and $R_{\mathrm{m}}$ were positively correlated with all chemistry and microbial variables (Table 3 ).

SEM revealed a significant causal relationship between sediment chemistry, EEA, and DHA (Fig. 6). The model explained $46 \%$ of the variance in sediment respiration $\left(\mathrm{DHA}_{;} \chi^{2}=42.0, \mathrm{df}=10, \mathrm{p}<0.0001\right)$. Significant paths in the model included positive relationships between TC, TN, BG, [NAG + LAP], and DHA.

\section{DISCUSSION}

Microbial carbon and nutrient demands are determined by the elemental stoichiometry of microbial biomass in relation to environmental carbon and 
nutrient availability (Schimel \& Weintraub 2003, Cleveland \& Liptzin 2007, Sinsabaugh et al. 2009). Ecological stoichiometric theory (EST) emphasizes the importance of the balance of biologically important elements for regulating an organism's response to, and regulation of, their environment (Sterner \& Elser 2002). EEA represents the interface between microbial demands for, and environmental supplies of, carbon and nutrients, effectively linking the EST (Sterner \& Elser 2002) with the concept of threshold elemental ratios (TER; Frost et al. 2006). EST proposes that biomass production and nutrient retention are governed by elemental ratios and the stoichiometric invariance of biomass; TER is the critical $\mathrm{C}: \mathrm{N}$ or $\mathrm{C}: \mathrm{P}$ ratio at which metabolism switches from energy flow (C acquisition) to nutrient limitation ( $\mathrm{N}$ or $\mathrm{P}$ acquisition). There are several models that link ecosystem-level interactions of organic matter, nutrients, and the role of microbial processes in the mediation of energy flow and nutrient cycling (Sinsabaugh \& Moorhead 1994, Schimel \& Weintraub 2003, Moorhead et al. 2012). These models highlight the interplay between microbial $\mathrm{C}$ acquisition to meet metabolic demands and the stoichiometric $\mathrm{N}$ and $\mathrm{P}$ requirements to support that level of metabolism. Sinsabaugh et al. (2009) used EEA stoichiometry to demonstrate the interaction of EST, TER, and the metabolic theory of ecology (MTE; Allen \& Gillooly 2009). MTE states that metabolism is the means by which organisms interact with their environments and the collective organisms' metabolism scales to the ecosystem level through energetic invariance, as evidenced by the positive correlation of our DHA measures and our estimated $R_{\mathrm{m}}$ for GOM sediments (Fig 5d). Sinsabaugh et al. (2009) used these models to predict microbial biomass $C, N$, and $P$ from EEA stoichiometry. As such, the relative activities of the functional classes of ecoenzymes are both a measure of nutrient availability and of ecosystem metabolism that may be used to assess large-scale phenomena such as regional impacts of anthropogenic disturbances.

The diagenic model described above suggests that most of the organic matter reaching the benthic zone is processed near the sediment surface, and this is reflected in decreasing sediment chemistry, DHA, EEA, $M$, and $R_{\mathrm{m}}$ with increasing sediment depth. The relatively high, and nearly constant, CUE suggests that the GOM benthic microbial community is efficient at converting available $\mathrm{C}$ into biomass, and that the conversion of $\mathrm{C}$ into biomass is limited by $\mathrm{C}, \mathrm{N}$, and $\mathrm{P}$ availability. CUE ranging from 0.33 to 0.56 indicates that more than half of the available $\mathrm{C}$ is being lost through respiration, resulting in decreasing $\mathrm{C}$ availability with increasing sediment depth. The similarity of the slopes of TC, TN, and TP losses with increasing sediment depth (Fig. 2a-c) indicates that, despite the respiratory $C$ losses, a relatively constant C:N:P stoichiometry is being maintained, supporting the idea that rapid re-mineralization of labile dissolved organic $\mathrm{C}$ is driving benthic metabolism in shallow coastal systems. Arnosti \& Holmer (2003) suggested that a rapidly turned-over DOC pool is necessary to support the levels of $\mathrm{C}$ oxidation measured in coastal sediments. They further indicated that a significant portion of this $\mathrm{C}$ oxidation occurs via anaerobic pathways (e.g. $\mathrm{SO}_{4}{ }^{2-}, \mathrm{Fe}^{2+}$, and $\mathrm{Mn}^{2+}$ reduction) resulting in many of the products of respiration being reduced forms of $\mathrm{C}$ and $\mathrm{N}$ subject to recycling back into anaerobic respiration and fermentation (Childs et al. 2002, Emerson \& Hedges 2006, Morse \& Eldridge 2007). This recycling of reduced products supports and stabilizes hypoxic/ anoxic conditions in the GOM, a feature termed the 'memory' or 'legacy' of nutrient enrichment and organic matter loading (Turner et al. 2008, Conley et al. 2009, Bianchi et al. 2010). A general assumption about sediment organic carbon is that it becomes more recalcitrant with increasing sediment depth, and this reduction in labile $\mathrm{C}$ availability limits microbial metabolism. However, Schimel \& Weintraub (2003) provide evidence that recalcitrant $\mathrm{C}$ is not necessarily the limiting factor, and that microbial metabolism is more often limited by $\mathrm{N}$ availability. The interaction of recalcitrant $\mathrm{C}, \mathrm{N}$ limitation (resulting in greater sequestration), and $\mathrm{C}$ and $\mathrm{N}$ recycling supports our observations of declining microbial activity with a constant CUE and declining $\mathrm{C}$ and $\mathrm{N}$ availability with increasing sediment depth.

Sediment microbial DHA and EEA also reflect the differences in $\mathrm{C}$ and $\mathrm{N}$ supply associated with the 4 zones of similarity. The prevailing wisdom states that coastal marine waters are primarily $\mathrm{N}$ limited (due to denitrification and $\mathrm{P}$ recycling), with periods and locales of P limitation (Sylvan et al. 2006). These watercolumn stoichiometries translate into spatial and temporal patterns that relate to the zones of similarity. $\mathrm{P}$ limitation of phytoplankton productivity is associated with higher Mississippi River flows during the spring, and with proximity to the Mississippi River plume and the coastal current that extends west from the Mississippi River beyond the mouth of the Atchafalaya River. $\mathrm{N}$ limitation is the rule for all other times and locales on the Louisiana Shelf (Sylvan et al. 2006). This pattern is consistent with our analyses of northern GOM shelf sediments, which are relatively 
$\mathrm{P}$ rich and $\mathrm{N}$ depleted. These differences are reflected in the DHA, EEA, and $R_{\mathrm{m}}$ data, with DHA and $R_{\mathrm{m}}$ highest near the Mississippi and Atchafalaya River plumes (Zones 1 and 2), suggesting an abundance of labile $\mathrm{C}$ and available $\mathrm{N}$ to support microbial metabolism. DHA and $R_{\mathrm{m}}$ decline with decreasing $\mathrm{N}$ availability in the remaining zones. These zonal differences are especially noticeable in the relative amount of $\mathrm{N}$-acquiring ([NAG + LAP]; Table 2) enzyme activity, which unexpectedly declines under $\mathrm{N}$-limiting conditions. This contradictory result suggests $\mathrm{N}$ limitation that is so severe as to inhibit microbial metabolism, a result consistent with the enzyme model predictions (Schimel \& Weintraub 2003).

The present study demonstrates the utility of microbial enzymes related to microbial respiration (DHA), nutrient acquisition (EEA), and organic matter decomposition ( $M$ and $R_{\mathrm{m}}$ ) for assessing ecosystem functions in benthic marine ecosystems. The proposed structural equation model quantified the linkages between sediment chemistry, EEA, and DHA. The spatial pattern of sediment microbial activity in the northern GOM is consistent with physico-chemical differences reported for the different zones of similarity (Lehrter et al. 2012), and provides some insight into relative $\mathrm{C}$ - and N-limitation of microbial activity. The change in microbial DHA and EEA with increasing sediment depth supports the concepts of nutrient recycling within the benthic environment, and the tight coupling of DHA and EEA with sediment chemistry suggests that microbial enzymes might provide insight into the importance of legacy effects on recovery from hypoxic conditions.

Acknowledgements. The USEPA Office of Water and the Gulf of Mexico Program Offices sponsored the surveys of the GOM hypoxic zone. We are indebted to the crew of the OSV 'Bold' who collected the field data. The views expressed in this paper are those of the authors and do not necessarily reflect the views or policies of the US Environmental Protection Agency. Mention of trade names or commercial products does not constitute endorsement or recommendation for use.

\section{LITERATURE CITED}

Allen AP, Gillooly JF (2009) Towards an integration of ecological stoichiometry and the metabolic theory of ecology to better understand nutrient cycling. Ecol Lett 12: 369-384

American Public Health Association (APHA) (1998) Standard methods for the examination of water and wastewater, 20th ed. Clesceri LS, Greenberg LE, Eaton AD (eds). American Public Health Association, Washington, DC

Arnosti C, Holmer M (2003) Carbon cycling in a continental margin sediment: contrasts between organic matter characteristics and remineralization rates and pathways. Estuar Coast Shelf Sci 58:197-208

> Arnosti C, Ziervogel K, Ocampo L, Ghobrial S (2009) Enzyme activities in the water column and in shallow permeable sediments from the northeastern Gulf of Mexico. Estuar Coast Shelf Sci 84:202-208

Bianchi TS, DiMarco SF, Cowan JH, Hetland RD, Chapman P, Day JW, Allison MA (2010) The science of hypoxia in the Northern Gulf of Mexico: a review. Sci Total Environ 408:1471-1484

Blenkinsopp SA, Lock MA (1990) The measurement of electron transport system activity in river biofilms. Water Res 24:441-445

> Broberg A (1985) A modified method for studies of electron transport system activity in freshwater sediments. Hydrobiologia 120:181-187

Burns RG, DeForest JL, Marxsen J, Sinsabaugh RL and others (2013) Soil enzymes in a changing environment: current knowledge and future directions. Soil Biol Biochem 58:216-234

> Cai WJ, Sayles FL (1996) Oxygen penetration depths and fluxes in marine sediments. Mar Chem 52:123-131

Childs CR, Rabalais NN, Turner RE, Proctor LM (2002) Sediment denitrification in the Gulf of Mexico zone of hypoxia. Mar Ecol Prog Ser 240:285-290

> Cleveland CC, Liptzin D (2007) C:N:P stoichiometry in soil: is there a 'Redfield ratio' for the microbial biomass? Biogeochemistry 85:235-252

> Conley DJ, Carstensen J, Vaquer-Sunyer R, Duarte CM (2009) Ecosystem thresholds with hypoxia. Hydrobiologia 629:21-29

> DeForest JL (2009) The influence of time, storage temperature, and substrate age on potential soil enzyme activity in acidic soils using MUB-linked substrates and L-DOPA. Soil Biol Biochem 41:1180-1186

> Diaz RJ, Rosenberg R (2008) Spreading dead zones and consequences for marine ecosystems. Science 321:926-929

Emerson S, Hedges J (2006) Sediment diagenesis and benthic flux. In: Elderfield H (ed) Treatise on geochemistry: the oceans and marine geochemistry, Elsevier, Oxford, p 293-319

> Foreman CM, Franchini P, Sinsabaugh RL (1998) The trophic dynamics of riverine bacterioplankton: relationships among substrate availability, ectoenzyme kinetics and growth. Limnol Oceanogr 43:1344-1352

> Frost PC, Benstead JP, Cross WF, Hillebrand H, Larson JH, Xenopoulos MA, Yoshida T (2006) Threshold elemental ratios of carbon and phosphorus in aquatic consumers. Ecol Lett 9:774-779

> Grace JB, Anderson TM, Olff H, Scheiner SM (2010) On the specification of structural equation models for ecological systems. Ecol Monogr 80:67-87

Hill BH, Herlihy AT, Kaufmann PR (2002) Benthic microbial respiration in Appalachian Mountain, Piedmont, and Coastal Plains streams of the eastern USA. Freshw Biol 47:185-194

> Hill BH, Elonen CM, Jicha TM, Cotter AM, Trebitz AS, Danz NP (2006) Sediment microbial enzyme activity as an indicator of nutrient limitation in Great Lakes coastal wetlands. Freshw Biol 51:1670-1683

Hill BH, Elonen CM, Jicha TM, Bolgrien DW, Moffett MF (2010) Sediment microbial enzyme activity as an indicator of nutrient limitation in the great rivers of the Upper Mississippi river basin. Biogeochemistry 97:195-209 
Hill BH, Elonen CM, Seifert LR, May AA, Tarquinio E (2012) Microbial enzyme stoichiometry and nutrient limitation in US streams and rivers. Ecol Indic 18:540-551

Jorgensen BB (1982) Mineralization of organic matter in the sea bed - the role of sulfate reduction. Nature 296: 643-645

Keiblinger KM, Hall EK, Wanek W, Szukics U and others (2010) The effect of resource quantity and resource stoichiometry on microbial carbon-use-efficiency FEMS Microbiol Ecol 73:430-440

Lee YB, Lorenz L, Dick LK, Dick RP (2007) Cold storage and pretreatment incubation effects on soil microbial properties. Soil Sci Soc Am J 71:1299-1305

Lehrter JC, Beddick DL, Devereaux R, Yates DF, Murrell MC (2012) Sediment-water fluxes of dissolved inorganic carbon, $\mathrm{O}_{2}$, nutrients, and $\mathrm{N}_{2}$ from the hypoxic region of the Louisiana continental shelf. Biogeochemistry 109: 233-252

Manzoni S, Taylor P, Richter A, Porporato A, Agren GI (2012) Environmental and stoichiometric controls on microbial carbon-use efficiency in soils. New Phytol 196: 79-91

Moorhead DL, Lashermes G, Sinsabaugh RL (2012) A theoretical model of $\mathrm{C}$ - and $\mathrm{N}$-acquiring exoenzyme activities, which balances microbial demands during decomposition. Soil Biol Biochem 53:133-141

Morse JW, Eldridge PM (2007) A non-steady state diagenic model for changes in biochemistry in response to seasonally hypoxic/anoxic conditions in the dead zone of the Louisiana Shelf. Mar Chem 106:239-255

Murrell MC, Lehrter JC (2011) Sediment and lower water column oxygen consumption in the seasonally hypoxic region of the Louisiana continental shelf. Estuaries Coasts 34:912-924

Packard TT (1971) The measurement of respiratory electron transport activity in marine phytoplankton. J Mar Res 29: 235-244

Rabalais NN, Turner RE, Justic D, Dortch Q, Wiseman WJ, San Gupta BK (1996) Nutrient changes in the Mississippi River and system responses on the adjacent continental shelf. Estuaries 19:386-407

Rowe GT, Cruz Kaegi ME, Morse JW, Boland GS, Escobar Biones EG (2002) Sediment community metabolism associated with continental shelf hypoxia, Northern Gulf of Mexico. Estuaries 25:1097-1106

Sampou P, Oviatt CA (1991) A carbon budget for a eutrophic

Editorial responsibility: Josep Gasol,

Barcelona, Spain marine ecosystem and the role of sulfur metabolism in sedimentary carbon, oxygen and energy dynamics. J Mar Res 49:825-844

Schimel JP, Weintraub MN (2003) The implications of exoenzyme activity on microbial carbon and nitrogen limitation in soil: a theoretical model. Soil Biol Biochem 35:549-563

Sinsabaugh RL, Follstad Shah JJ (2011) Ecoenzymatic stoichiometry of recalcitrant organic matter decomposition: the growth rate hypothesis in reverse. Biogeochemistry 102:31-43

Sinsabaugh RL, Foreman CM (2001) Activity profiles of bacterioplankton in a eutrophic river. Freshw Biol 46: 1239-1249

Sinsabaugh RL, Moorhead DL (1994) Resource allocation to extracellular enzyme production: a model for nitrogen and phosphorus control of litter decomposition. Soil Biol Biochem 26:1305-1311

Sinsabaugh RL, Findlay S, Franchini P, Fisher D (1997) Enzymatic analysis of riverine bacterioplankton production. Limnol Oceanogr 42:29-38

> Sinsabaugh RL, Hill BH, Follstad Shah JJ (2009) Ecoenzymatic stoichiometry of microbial organic nutrient acquisition in soil and sediment. Nature 462:795-798

Sinsabaugh RL, Follstad Shah JJ, Hill BH, Elonen CM (2012) Ecoenzymatic stoichiometry of stream sediments with comparison to terrestrial soils. Biogeochemistry 111: 455-467

Sinsabaugh RL, Manzoni S, Moorhead DL, Richter A (2013) Carbon use efficiency of microbial communities: stoichiometry, methodology and modeling. Ecol Lett 16: 930-939

Sterner RW, Elser JJ (2002) Ecological stoichiometry: the biology of elements from molecules to the biosphere. Princeton University Press, Princeton, NJ

Sylvan JB, Dortch Q, Nelson DM, Maier Brown AF, Morrison W, Ammerman JW (2006) Phosphorus limits phytoplankton growth on the Louisiana Shelf during the period of hypoxia formation. Environ Sci Technol 40: 7548-7553

- Trevors JT, Mayfield CI, Inniss WE (1982) Measurement of electron transport system (ETS) activity in soil. Microb Ecol 8:163-168

Turner RE, Rabalais NN, Justic D (2008) Gulf of Mexico hypoxia: alternative states and a legacy. Environ Sci Technol 42:2323-2327

Submitted: May 3, 2013; Accepted: February 11, 2014

Proofs received from author(s): April 14, 2014 